\title{
The motherhood experience in the context of social vulnerability: a comprehensive approach to social phenomenology ${ }^{1}$
}

\author{
Luz Angélica Muñoz ${ }^{2}$ \\ Ximena Sanchez ${ }^{3}$ \\ Estela $\operatorname{Arcos}^{4}$ \\ Antonia Vollrath ${ }^{5}$ \\ Carla Bonatti ${ }^{6}$
}

\begin{abstract}
Objective: to understand the future expectations and experience of vulnerable mothers from pregnancy to their child's early years. Methods: this qualitative study used the social phenomenology of Alfred Schütz as a framework. From January to April 2011, nine mothers from the 2009 program "Chile Grows with You" were interviewed at health centers in an urban Santiago de Chile community. Results: analysis of the "lived type" led to an understanding of the mothers' real-world experience. Unexpected pregnancies in extremely vulnerable mothers are associated with feelings of hopelessness then resignation. There is no plan for the future; the mother lives in the present with great uncertainty. Conclusions: from the mothers' stories, significant patterns were identified in their experiences, yielding insights into society from these women's perspectives. For humanized, comprehensive nursing care, this expertise directs interventions designed to overcome despair in women excluded because of their invisibility and poverty.
\end{abstract}

Descriptors: Social Vulnerability; Social Policy; Public Health; Nursing.

\footnotetext{
${ }^{1}$ Paper extracted from master's thesis "Vivencia de una madre e hijo en situación de vulnerabilidad. Un abordaje Fenomenológico Social" presented to Facultad de Enfermería, Universidad Andrés Bello, Santiago, Chile. Supported by Universidad Andrés Bello, Vicerrectoría de Investigación y Doctorado, procesS \# DI-21-10/R.

${ }^{2} \mathrm{PhD}$, Full Professor, Facultad de Enfermería, Universidad Andrés Bello, Santiago, Chile.

${ }^{3}$ MSc, Full Professor, Facultad de Ciencias Sociales, Universidad de Playa Ancha, Valparaíso, Chile.

${ }^{4} \mathrm{MSc}$, Full Professor, Facultad de Enfermería, Universidad Andrés Bello, Santiago, Chile.

${ }^{5}$ MSc, Assistant Professor, Facultad de Enfermería, Universidad Andrés Bello, Santiago, Chile.

${ }^{6}$ Master's student, Facultad de Enfermería, Universidad Andrés Bello, Santiago, Chile.
} 


\section{Introduction}

The analytical perspective of the social, cultural and political determinants of health has elucidated the mechanism underlying the "causes of the causes" of health problems and, in turn, identified the routes or sources of inequities regarding maternity ${ }^{(1-2)}$. The evidence reveals that reproductive, neonatal, mental and family health deteriorates when women are employed in precarious jobs, become pregnant with no social security, have an informal and unsafe housing situation, have a low educational level, lack a partner in the home and when there is a psychosocial risk associated with inadequate family support, symptoms of depression, gender violence, substance abuse and conflicts with motherhood $^{(3)}$.

It has been established that the most vulnerable social situation is associated with higher levels of stress and anxiety of the mother both before and during pregnancy. This increased stress then leads to an increased incidence of prematurity, low birth weight, early weaning, poor quality of childcare, higher rates of lag, child developmental delay, attention deficit hyperactivity disorder, speech problems, depression and poor social competence in the behavior of the individual for life ${ }^{(4-5)}$

Bearing in mind the significance of the adverse sociocultural determinants of motherhood and parenting, international agencies have posed the challenge of demonstrating the diversity of experiences of mothers living in socially vulnerable contexts; this challenge was included in the International Initiative for Safe Motherhood. The present study is justified by the need to generate knowledge about women as a whole and to try to understand women as people belonging to a social group with unique characteristics that are collectively constructed and accepted and that influence the way women's health problems and needs are perceived. The purpose of the study was to reveal vulnerable motherhood, to understand life's experiences from the perspectives of these women from pregnancy through the first two years of their child's life. The following objective was considered: Understanding the lived experience of vulnerable mothers from pregnancy to the early years of their child's life and these mother's expectations for the future. This process overcomes the reductionist view of motherhood revealed by classic epidemiological profiles and the reports of health care systems ${ }^{(5-7)}$.

The following concerns arose in relation to the phenomenon under study: What has been the experience of the vulnerable mother during pregnancy? How is it expected to be in the future? What was her experience with the support offered by the health care team? And how do these mothers experience raising their children in a vulnerable situation?

Currently the concept of vulnerability is defined as a distinct and characteristic social feature of the current pattern of economic development in Latin America and the Caribbean. According to the researcher, this concept can explain some of the social problems of the late 20th century. The concept of vulnerability is complementary to the approach of poverty and income distribution used at present, with the explanatory type components "the insecurity and helplessness experienced by communities, families and individuals in their lives as a result of the impact caused by some kind of traumatic social economic event", on the one hand, and "the management of resources and strategies used by communities, families and individuals to deal with the effects of that event" on the other hand ${ }^{(8)}$. The concept of vulnerability allows for a broader view of people's lives in the world and an understanding of what it means to lack autonomy in addressing health problems. Additionally, understanding the concept of vulnerability allows for the investigation of the impact of protective strategies that provide economic resources to individuals and families to ease the adverse situation and its impact on health and health problems ${ }^{(6-7)}$.

The socialization process that takes place in families is determined by their social status and other relevant categories and extends in its primary stage from birth to 8 or 10 years of age, depending on the characteristics of the child and the family socialization patterns ${ }^{(9)}$. It is worth mentioning that everything that is assimilated at this primary stage is affected by a strong emotional tone that is established between the child and significant ones. At this stage, the attachment theory of John Bowlby is particularly important, which describes a critical role in the affective relationship that is established between the child and what many authors call "primary caregivers". In this regard, the fields of psychopathology, clinical psychology, health sciences, social sciences, social programs and child protective services have been transformed by the theory that the psychiatrist and psychoanalyst John Bowlby proposed to understand how early affective interactions between caregiver and infant affect later human biopsychosocial development $(7,10)$. From the perspective of child psychology and from the sociology of the family, the existence of a secure attachment and the rearing 
patterns that involve care and protection during the early stages of child development are conditions that continue in the other stages of development of the person ${ }^{(9)}$.

Under this premise, there is a consensus that countries with high levels of social inequality should incorporate public policies for social protection as a response to the poverty and vulnerability created by social inequality ${ }^{(4)}$. These policies would integrate programs in public institutions, whose purpose is to protect people and their homes and help them to produce assets to mitigate their social vulnerability condition ${ }^{(3)}$. In Chile, as a form of integrating families into society, the social protection system has put poor early childhood at the center (fairness from the beginning). The social protection system has directed its action on the basis of four main objectives: a) the health and nutrition of the pregnant woman, the mother and the child; b) preparing children for school; c) facilitating the employment of the mother; and d) caring for children in situations of high social risk or who have had their rights violated and providing benefits to the families contained in the programs associated with the social safety net Protect Network (Red Protege)(11).

This study used The Phenomenology of the Social World by Alfred Schütz as a philosophical framework mainly because of its interpretative and comprehensive character in providing meaning to the actors in their everyday world while they seek the experiences of living and in their relationships to other actors and to the features of the "action projects" that they formulate. The everyday-life world is common to us all, and in it, each one lives and acts as a man among his peers. This world can be understood as a playground for action and possible orientations that are organized around persons based on the specific blueprint of their plans and the meanings derived from them. This study attempts to understand the phenomenon in a holistic way in a particular human group that is attached to a particular set of circumstances ${ }^{(12-13)}$.

Within this philosophical framework, the focus of interest is to uncover the meaning of the everyday-life world of existence and living with others, contextualizing intersubjectivity and creating a social group ${ }^{(12)}$. Two groups of reasons have been identified in social behavior for understanding motivation: the "reasons for", which are the desired goals for the future and constituted by subjectivity and reaching for what is to be accomplished through action; and the "reasons why", which explain the action scene with regard to past experience, the acquired and transmitted knowledge that constitutes cultural heritage and the knowledge gained through personal experience ${ }^{(12-13)}$.

\section{Objective}

The goal of this study was to understand the lived experience of mothers in a vulnerable situation from pregnancy to the early years of their child's life and the expectations of these mothers for the future.

\section{Methods}

The research was conducted from the perspective of the qualitative paradigm, which is characterized by "searching unknown or little known dimensions of a social fact. These dimensions are also sought on the basis of which those groups affected by it live and understand that social fact"(14).

According to the social phenomenology of Alfred Schütz, "the everyday-life world is common to all people and exists because we live in it as men, with other men with whom we are linked by common influences and efforts, realizing the truth and being understood by them"(12-13).

The method used was the phenomenological interview, which takes place at a social gathering event that displays features such as empathy, intuition and imagination; the researcher proposed a peacefu meeting, which allowed for a fluent dialogue on the part of the mothers ${ }^{(15)}$.

The subjects of the investigation were nine mothers admitted for pregnancy at any gestational age to the program Chile Grows with You in a health center in the municipality of Pudahuel in the Province of Santiago, Chile. The inclusion criteria were as follows: having a live-born child of 12-24 months of age who lived with her and whose family of origin was stratified within the lower $40 \%$ of the most vulnerable population. The interviews were conducted between January and April 2011.

The technique chosen for the research was the phenomenological interview, defined as "repeated face-to-face encounters between the researcher and interviewees, which were directed toward understanding the perspectives of the interviewees about their lives, experiences and situations, as expressed in their own words"(13-15). The use of the technique is justified because the researcher is able to describe the way in which mothers see themselves by relating their personal events, which are linked to the most central aspects of their daily lives. 
The number of subjects was defined from the time it was perceived that the content of the discourses unveiled the phenomenon investigated and provided answers to the research questions. Ethical procedures were complied with by providing a prior detailed explanation to the subjects and using terms that were understandable within the social reality of the interviewees.

The study was approved by the Scientific Ethics Committee of the School of Nursing at the Andrés Bello University, \# L1/CECENF/14. The maximum length of the interviews was 60 minutes. The interviews were recorded, transcribed and read carefully, looking for the convergence of the "reasons for" and "reasons why" that were experienced in the issues that were subsequently categorized. Specific groups or categories of lived experiences were identified by recognizing the essential content of the stories. The categorization of the units of stories presupposes a view of the object in its reduction and not a natural classification. This means that, from the beginning, the phenomenological method is used to reach a pre-categorization that allows us to make a phenomenologically oriented selection of the most relevant units of meaning of a certain story $^{(16)}$. To establish the quality of the qualitative data, the approaches set by Flick ${ }^{(17)}$ were used, as well as triangulation from the researchers; in this case, the data were analyzed and validated by more than one researcher ${ }^{(18)}$.

\section{Results}

From the categories and subcategories, it was possible to understand the meaning that the women gave to the experience of being a mother within their contexts of vulnerability. The categories are exemplified by some distinctive references from the analyzed interviews, which are noted by italics below.

\section{Resignation to their living conditions ("reasons why")}

This category includes the following subcategories: Unwanted pregnancy, Resignation and acceptance and Working to survive.

Commonly, the experience of motherhood is considered to be unique and surrounded by meanings of hope and promise; however, the stories illustrate a different situation. When the vulnerable mother becomes pregnant, she experiences mixed feelings of desolation and hopelessness. Pregnancy was not in the immediate present, which is the reason why she receives and accepts a confirmation of her pregnancy with confusion and despair. The awareness of her pregnancy is unexpected in her current life plan, given the importance that the present has for those living in poverty. The surprise of pregnancy, a recognition of the current difficulty of existence and then resignation and acceptance of the burden that the pregnancy implies can be discerned in the following stories: and I began to cry ... all I could think was that God sent me my son for something, perhaps something He has in store ... So there we are ... should be used to it ... I did not rest, for me my life is working, bearing my children, when I was little I lacked many things and I do not want the same for my children. This is what Schütz called "lifeworld".

\section{Facing motherhood with contradictions ("reasons why")}

This category incorporates the following subcategories: Complications, Identifying differences, Gratitude for benefits, Differences between their children, and Learning to be a mother.

The mother in poverty faces motherhood with contradictions derived in great part from the precariousness of their existence, which includes the following: being a female head of household, underemployment (if employed at all), complications in the process of pregnancy, childbirth and postpartum symptoms. However, these conditions are related to the recognition of differences from previous situations of motherhood, thanks to the support received in the context of her precariousness, and a distinctive evaluation capacity with regard to the parenting of her other children that was linked to the positive learning of motherhood. According to Schütz, this would be the natural attitude of the mother to cope with her current life situation.

...between problems, I was depressed, in pregnancy and after pregnancy, also... I have nothing to say about the second one at all... at the end of pregnancy doctors treated me well, really well... nowadays, it is good because they tell you how to stimulate babies when they are little ones... I find that children increasingly come more alive...

\section{Hope and hopelessness about the future ("reasons for")}

This category includes the following subcategories: Hope in the future, The future of their children, the Basis of education, and Uncertainty for the future.

Despite the difficulty of existence, difficult experiences and the difficulty of experiencing mixed feelings during the process of motherhood, the data from the interviews indicate a sense of hope that modifies 
in part the feeling of learned hopelessness present in people living in poverty.

The mother recognizes her importance in building a future for her children and the significance of the maternal role both in the first stage and in the following processes of upbringing and socialization; education is valued as a process in itself that is very present in the stories. However, coupled with this, the future is still uncertain; childcare is seen with great uncertainty, and the possibility of another pregnancy is considered to be the most feared threat:... I had ups and downs as the whole family, but we support each other; we are family, and the teaching that we are giving our children is healthy... I think they will be happy and make us happy and help us to overcome our little problems that we have between us... I would like my son to have his profession, to continue to study and later have his profession, his career ... I will not have another child, I would die. Four is enough, and five I would die, and I do not want to die, I want to live ...

\section{Feeling invisible to the health care team ("reasons why")}

This category includes the following subcategories: Lack of effective communication, Fear of not being heard or understood, Satisfaction in terms of delivered care, Feeling heard.

Mothers have observed situations that they describe and that attest to their feeling of invisibility vis a vis the health care team, which affects interaction and dialogue. This may be explained, in part, by the low symbolic and linguistic capital of the people, which creates difficulties in understanding the interactions that occur in health facilities, and the limited perception and understanding that providers have with regard to the degree of vulnerability and social needs of the people to which they attend. At the same time, other individuals have positive experiences, in which there is an assessment and recognition of the effort put forth and the good quality of care received. According to the concepts of Schütz, the face-to-face relationship between the mother and the health care personnel is revealed, wherein the mother experienced a condition of invisibility, powerlessness and anger because of not feeling supported or understood.

... suddenly they become angry because you do not ask, then, if you ask they become angry... nobody helped me, they received my baby when delivered, that was all they did, they received my baby... a new office was assigned to us; it was too good, better than the other; the same nurses, doctors, all were really good, like private care, and it was so super good and all were concerned... There is a nurse that I like how she cares for me, how she cares for the child...
The comprehensive analysis of the lived type allowed for an understanding of the lived experience of the mother in her real-world existence and an understanding of her motivations and expectations for the future. Being a mother again in a situation of extreme vulnerability is something that takes her by surprise and generates feelings of hopelessness and despair, which later evolve into resignation, acceptance and a realization of the burden pregnancy entails. There is no plan for the future; the mother lives in the here and now with great uncertainty.

\section{Discussion}

Further knowledge, from the mother's perspective, of the experience of being a mother under conditions of extreme vulnerability was achieved. In the stories a type of maternity, perceived as a negative event that was unexpected and assumed with resignation and anguish, was unveiled. To some authors, this situation causes internal disorganization and broken links and generates depression syndromes(19). The feelings of frustration, despair and loneliness that are evident in the analysis of the interviews, both with regard to the unexpected and the unwanted pregnancy, are consistent with the precariousness of the social support and the uncertainty that the mothers have their contexts of social vulnerability ${ }^{(13,20)}$.

The mothers describe a life situation where the social construction of despair, invisibility and social exclusion takes place naturally and whose substrate is constituted by social and economic inequalities. It has been reported that in most cultures, the groups of women who are mothers in conditions of poverty share common life scenarios and stories that affect motherhood, childcare and the practice of their sexual and reproductive rights(21)

The process leading to resignation manifests itself as a feeling of learned hopelessness: I am poor; I was born poor, and will die poor; I am resigned. This concept, which has already been described in the interpretation of the categories, affects their possibilities for self-determination, autonomy and the enjoyment of minimum welfare rights. The feeling of living in poverty reinforces the social dependence on others and forces them to build family support and solidarity networks to cope with motherhood and parenting in a safer and socially protected environment(21).

The phenomenological approach of Alfred Schütz ${ }^{(13)}$ allowed for the understanding of the experiences of 
the mothers in their everyday-life world, where they perceive themselves as invisible to the attending staff in their relationship with health care centers. The situation of the invisibility of women is not an isolated issue. Studies from a gender perspective of women living in poverty indicate the existence of an invisible woman, who does not exist except in the everyday natural world of her existence; the more difficulties these women face in exercising motherhood and the care of their children, the farther they are from procuring a project that justifies the exercise of their fundamental human rights, thereby revealing the social exclusion faced by themselves and their children(21). It is important to note that they have an intuition about the lack of understanding of their condition of vulnerability and poverty that explains the perceived distance with the attending staff. The above takes place in a superficial interaction with health personnel, reinforced by asymmetrical relations and the invisibility of social vulnerability ${ }^{(3,13,22)}$.

Understanding the lived experience of vulnerable mothers provides substantive elements that can be utilized in providing a humanized and comprehensive health care practice, one that is sensitive to the needs of the specific person with whom there is a relationship within the space of fundamental rights for women and children ${ }^{(13,21,22-24)}$. The results demonstrate the importance of providing better and increased attention to the most vulnerable, invisible and unprotected groups not only to strengthen the comprehensive prevention efforts and to promote parenting skills to enable them to adequately care for and attend to their children but also as a way to create a space for communication, resilience and personal and family psychosocial development and the respect for human rights(13,20,22).

\section{Conclusion}

From the critical reflection and interpretation of the stories of mothers, significant patterns of the lived experiences in their personal and family environments have been identified that provide insight for better understanding the social world from the particular perspective of vulnerable women. In the construction of concepts, theories and models for a humanized and comprehensive health care practice in the nursing field, this knowledge constitutes scientific evidence that facilitates the social relevance of the design and implementation of strategies to help overcome the hopelessness that immobilizes and reinforces the fatalism learned in women who feel excluded by their invisibility and poverty.

\section{References}

1. Schofield T. Health inequity and its social determinants: A sociological commentary. Health Sociol Rev. 2007; 16:105-14.

2. Song R, Hall H, McDavid K, Telfair T, Lin L, Dean $H$. Identifying the impact of social determinants of health on disease rates using correlation analysis of area-based summary information. Public Health Reports. 2011;126 (S3): 70-80. Inglés.

3. Arcos E, Muñoz LA, Sánchez X, Vollrath A, Latorre

$C$, Bonatti $C$, et al. Vulnerabilidad Social en mujeres embarazadas de una comuna de la Región Metropolitana. Rev Med Chile. 2011;139(6):739-47.

4. Organización Mundial de la Salud. Subsanar las desigualdades en una generación. Alcanzar la equidad sanitaria actuando sobre los determinantes sociales de la salud. Organización Mundial de la Salud; 2008. [acesso 21 jan 2012]. Disponivel em: http://www.who.int/.

5. Castro Franco BE, Penaranda Correa F. La comprensión de los significados de la maternidad: el caso de un programa de cuidado prenatal en un centro de salud en Popayán, Colombia. Salud Colectiva. $2011 ; 7(3): 333-45$.

6. Nichiata L, BertolozziI MR, Takahashi R, Fracolli L. The use of the "vulnerability" concept in the nursing area. Rev. Latino-Am. Enfermagem. 2008;16(5):923-8.

7. Pettengill MAM, Angelo M. Family vulnerability: concept development. Rev. Latino-Am. Enfermagem. 2005;13(6):982-88.

8. Pizarro R. La vulnerabilidad social y sus desafíos: una mirada desde América Latina, CEPAL. Serie Estudios Estadísticos y Prospectivos. 2001;6:1-71 [acesso 12 mar 2012]. Disponivel em: http://www.eclac.cl/ publicaciones/xml/3/6553/lcl1490e.pdf

9. Gómez Muzzio E, Muñoz M, Santelices P. Efectividad de las Intervenciones en Apego con Infancia Vulnerada y en Riesgo Social: Un Desafío Prioritario para Chile. Terapia Psicol. 2008;26(2):241-51.

10. Esser I, Ferrarini T, Nelson K, Sjöberg O. Cadre de comparaison de la protection sociale entre pays développés et en développement: les prestations pour enfants. Rev Int Sécurité Soc. 2009;62:99-126.

11. Raczynski D. Política de infancia temprana en Chile: Condicionantes del desarrollo de los niños. [acesso 4 abril 2012]. Disponivel em: http://www.oei.es/inicial/ articulos/politica_infancia_temprana_chile.pdf. 
12. Ramírez A, Angelo M, González LA. Vivencias de estudiantes de enfermería de la transición a la práctica profesional: un enfoque fenomenológico social. Texto Contexto- Enferm. 2011;20:66-73.

13. Merighi M, Rodrigues R. Domingos S. Care needs of pregnant women with a private health insurance: a comprehensive social phenomenology approach. Rev. Latino-Am. Enfermagem. 2007;15(5):914-21.

14. Cavaria L. Fundamentos del paradigma cualitativo, En la investigación educativa. Rev Ciencias Ejercicio Salud. 2006;4(1):42-51.

15. Muñoz LA, Erdmann AL. La fenomenología en la producción de conocimientos en enfermería. In: Prado $M L$, Souza ML, Carraro TE. Investigación cualitativa en enfermería: contexto y bases conceptuales. Washington (DC): OPS; 2008. p. 101-16.

16. Terra MG, Silva LC, Camponogara S, Santos EKA, Souza AIJ, Erdmann AL. Na trilha da fenomenologia: um caminho para a pesquisa em enfermagem. Texto Contexto-Enferm. 2006;15(4):672-8.

17. Fernandes $M$, Merighi M, Muñoz LA. La experiencia de las enfermeras clínicas con estudiantes de enfermería: un análisis fenomenológico. Rev ESC Enferm USP. 2009;43(3):528-34.

18. Cisternas F. Categorización y triangulación como procesos de validación del conocimiento en investigación cualitativa. Theoria. 2005;14(1):61-71.

19. Merighi M, Conçalves R, Rodrigues E. Vivenciando o período puerperal: uma abordagem compreensiva da Fenomenologia Social. Rev Bras Enferm. 2006;59(6):775-9.

20. Rojas I, Caba MA. Una experiencia de mejora de las habilidades para la parentalidad y el desarrollo sociopersonal de los menores en contextos de desprotección social. Intervención Psicosocial. 2009;18(2):135-51.

21. Matar L, Dinis C. Hieraquias reproductivas: Maternidade e desigualdades no exercício de direitos humanos pelas mulheres. Comunic., Saude, Educ. 2012;16(40):107-19.

22. Conçalves $R$, Aguiar $C$, Merighi $M$, Jesus $M C$. Vivenciando o cuidado no contexto de uma casa de parto: o olhar das usuárias. Rev Esc Enferm USP. 2011;45(1):62-70.

23. León F. Pobreza, vulnerabilidad y calidad de vida en América Latina: Retos para la bioética. Acta Bioeth. 2011;17(1):19-29.

24. Canaval GE, González M C, Tovar M C, Valencia C. La experiencia de las mujeres gestantes: "lo invisible". Invest Educ Enferm. 2003; 21(2):32-46. 